\title{
PENGGUNAAN SUMBER BELAJAR DENGAN PENDEKATAN MULTILITERASI SISWA KELAS IX-C SMP NEGERI 27 TEBO PADA MATA PELAJARAN PPKN
}

\author{
Reski Wilarsih, Dona Sariani, \& Irwan \\ Universitas Jambi \\ Email: wilarsihreski@gmail.com, donasariani@unja.ac.id, \& $\underline{\text { irwansyawir@gmail.com }}$
}

\begin{abstract}
Abstrak
Berdasakan hasil observasi awal yang dilakukan peneliti di SMP Negeri 27 Tebo menunjukkan masalah pada penggunaan sumber belajar dengan pendekatan multiliterasi siswa. Masalah yang dimaksud yaitu pada penggunaan sumber belajar untuk mendukung pembelajaran khususnya pada mata pelajaran PPKn, di mana siswa masih berpedoman pada Lembar Kerja Siswa (LKS) dan buku paket yang dimiliki siswa dari sekolah, tanpa didukung dengan referensi lain. Tujuan penelitian ini adalah untuk mendeskripsikan penggunaan sumber belajar dengan pendekatan multiliterasi siswa kelas IX-C SMP Negeri 27 Tebo. Penelitian ini dilaksanakan di SMP Negeri 27 Tebo pada 07 September s/d 07 November 2020. Informan penelitian ini adalah guru mata Pelajaran PPKn, waka bidang kurikulum, dan siswa kelas IX-C (8 orang). Metode pengumpulan data pada penelitian ini adalah pengumpulan data kualitatif yaitu observasi, wawancara, dan dokumentasi. Teknik analisis data penelitian ini adalah deskriptif kualitatif. Hasil penelitian menunjukkan bahwa penggunaan sumber belajar dengan pendekatan multiliterasi siswa kelas IX-C SMP Negeri 27 Tebo pada mata pelajaran PPKn masih berpedoman pada buku cetak dan LKS dari pemerintah. Kesimpulan penelitian ini adalah bahwa Penggunaan sumber belajar dengan pendekatan multiliterasi siswa kelas IX-C SMP Negeri 27 Tebo pada mata pelajaran PPKn belum efektif. Sumber belajar yang digunakan masih berpedoman pada buku cetak dan LKS dari pemerintah.
\end{abstract}

Kata Kunci: Sumber Belajar, Multiliterasi, Pembelajaran PPKn

\begin{abstract}
Based on the results of initial observations made by researchers at SMP Negeri 27 Tebo showed problems in the use of learning resources with a multiliteration approach of students. The problem in question is the use of learning resources to support learning, especially in VAT subjects, where students are still guided by Student Worksheets (LKS) and package books owned by students from school, without being supported by other references. The purpose of this study is to describe the use of learning resources with the multiliteration approach of students of class IX-C of State Junior High School 27 Tebo. This research was conducted at SMP Negeri 27 Tebo on September 07 to November 7, 2020. Informants of this study are teachers of PPKn subjects, waka curriculum field, and students of class IX-C (8 people). The method of data collection in this study is qualitative data collection, namely observation, interview, and documentation. This research data analysis technique is qualitative descriptive. The results showed that the use of learning resources with the multiliteration approach of students of class IX-C of State Junior High School 27 Tebo in VAT subjects is still guided by printed books and LKS from the government. The conclusion of this study is that the use of learning resources with the multiliteration approach of students of class IX-C of State Junior High School 27 Tebo on VAT subjects has not been effective. The learning resources used are still guided by printed books and LKS from the government.
\end{abstract}

Keywords: Learning Resources, Multiliteration, VAT Learning

\section{PENDAHULUAN}

Pendidikan merupakan hal yang pokok bagi suatu negara. Oleh sebab itu, perlu dilakukan Pendidikan secara terencana dalam mengembangkan kualitas sumber daya manusia. Dengan menyediakan berbagai komponen Pendidikan yang diperlukan peserta didik sebagai penunjang proses pembelajaran, diharapkan dapat terciptanya sumber daya yang kreatif dan inovatif. Proses pembelajaran juga harus disesuaikan 
dengan perkembangan zaman (Nurgiansah, 2018) (Nurgiansah, 2019). Sistem pembelajaran pada abad sekarang ini merupakan suatu peralihan, di mana pendekatan pembelajaran yang diterapkanbukan lagi berpusat kepada guru, melainkan berpusat pada siswa. Guru diharuskan menciptakan suatu pembelajaran agar siswa mampu menemukan makna sendiri atas sebuah informasi sehingga akan terbentuk kemampuan berpikir pada diri siswa.

Menurut Cahyadi (2019:6) dan (Nurgiansah, 2021) sumber belajar adalah semua sumber yang dapat mempermudah peserta didik dalam mencapai tujuan belajar. Baik dalam bentuk data, orang dan wujud tertentu. Di dalam pembelajaran saat sekarang, guru harus mampu menggunakan sumber-sumber belajar yang multiliterasi, sehingga tidak hanya mengandalkan sumber-sumberbelajar yang konvensional saja. Multiliterasi mengandung pengertian sebagai keterampilan menggunakan beragam cara untuk menyatakan dan memahami ide-ide dan informasi dengan menggunakan bentuk-bentuk teks konvensional maupun teks inovatif, symbol, dan multimedia (Abidin, 2018:51) (Nurgiansah, 2020). Artinya Sumber belajar berperan sangat penting dalam proses pembelajaran, karena selain memudahkan guru dan siswa dalam proses pembelajaran, sumber belajar juga dapat dimanfaatakan siswa agar dapat meningkatkan kualitas belajar dan memperkaya pengalaman belajarnya. Dengan demikian tujuan pembelajaran yang sudah ditetapkan dapat tercapai.

Dewasa ini, penggunaan sumber belajar berupa buku teks sangat dominan. Sumber belajar yang digunakan siswa, khususnya dalam pembelajaran PPKn masih berpedoman pada Lembar Kerja Siswa (LKS) dan buku paket yang dimiliki siswa dari sekolah, tanpa didukung dengan referensi lain. Dampak yang ditimbulkan dari pembelajaran yang demikian yaitu, siswa kurang bergairah dan kurang perhatian dalam mengikuti pembelajaran. Pembelajaran cenderung membosankan dan menjenuhkan, siswa cenderung pasif serta capaian pembelajaran siswa kurang maksimal. Berdasarkan data yang telah peneliti peroleh, diketahui capaian pembelajaran siswa kelas IX-C masih tergolong rendah, yaitu sebanyak 16,7\% yang mencapai nilai KKM. Untuk mengetahui penggunaan sumber belajar dengan pendekatan multiliterasi siswa pada mata pelajaran PPKn, maka diperlukan pengamatan terhadap guru dan siswa.

Berdasakan observasi awal yang dilakukan peneliti di SMP Negeri 27 Tebo, penggunaan sumber belajar untuk mendukung pembelajaran khususnya pada mata pelajaran PPKn belum efektif. Hal ini ditandai dengan sumber belajar yang digunakan siswa dalam pembelajaran PPKn masih berpedoman pada Lembar Kerja Siswa (LKS) dan buku paket yang dimiliki siswa dari sekolah, tanpa didukung dengan referensi lain. Sehingga siswa hanya terpaku pada materi yang ada di LKS dan buku paket.

Fakta dilapangan, pembelajaran PPKn di SMP Negeri 27 Tebo masih berpusat kepada guru. Komunikasi yang digunakan hanya bersifat komunikasi satu arah. Guru masih terbiasa menggunakan metode pembelajaran yaitu berupa ceramah. Guru kurang mampu memotivasi siswa untuk bertanya. Sehingga siswa terbiasa hanya menerima informasi yang di sampaikan guru. Siswa hanya mengandalkan gurunya sebagai sumber belajar, tanpa mengembangkan atau mencari tahu sendiri sumber-sumber belajar lainnya.

Dampak yang ditimbulkan dari pembelajaran yang demikian yaitu, siswa kurang bergairah dan kurang perhatian dalam mengikuti pembelajaran. 
Pembelajaran cenderung membosankan dan menjenuhkan, sehingga peserta didik kesulitan dalam memahami materi yang dijelaskan oleh guru, siswa cenderung pasif serta capaian pembelajaran siswa kurang maksimal. Hasil observasi yang dilakukan di SMP Negeri 27 Tebo, diketahui bahwa hasil belajar PPKn siswa kelas IX-C masih cenderung rendah. Hasil belajar yang kurang memuaskan tersebut terlihat dari hasil Ujian Tengah Semester (UTS) berikut:

Tabel 1.1 Rekapitulasi Nilai Rata-Rata Ujian Tengah Semester Siswa Kelas IX-C SMP Negeri 27 Tebo pada Mata Pelajaran PPKn

Sumber: Guru mata pelajaran PPKn

\begin{tabular}{|c|c|c|c|c|c|}
\hline \multirow{2}{*}{ KELAS } & \multirow{2}{*}{ JUMLAH SISWA } & \multicolumn{2}{|c|}{ TUNTAS } & \multicolumn{2}{c|}{ TIDAK TUNTAS } \\
\cline { 3 - 6 } & & $\geq \mathbf{7 0}$ & $\%$ & $\leq 70$ & $\%$ \\
\hline IX-C & 30 & 5 & $16.7 \%$ & 25 & $\mathbf{8 3 . 3 \%}$ \\
\hline
\end{tabular}

Berdasarkan data di atas, terlihat bahwa dari 30 siswa yang mampu mencapai nilai KKM sebanyak 5 siswa atau 16.7\%. Sedangkan siswa yang tidak mencapai nilai KKM sebanyak 25 siswa atau 83.3\%. Dari data tersebut, menunjukkan bahwa rata-rata nilai ujian tengah semseter (UTS) masih di bawah KKM. Kriteria Ketuntasan Minimal (KKM) adalah tingkat pencapaian kompetensi dasar yang harus dicapai oleh siswa per mata pelajaran. SMP Negeri 27 Tebo memiliki standar KKM khususnya pada mata pelajaran PPKn yaitu 70. Apabila siswa yang belum mencapai kriteria nilai yang diharapkan, maka siswa tersebut harus mengikuti remedial.

\section{METODE PENELITIAN}

Penelitian ini menggunakan penelitian kualitatif dengan jenis penelitian deskriptif kualitatif. Menurut Sugiyono (2018: 207), menyatakan bahwa metode deskriptif adalah suatu metode yang digunakan untuk menganalisis data dengan cara mendeskripsikan atau mengaggambarkan data yang telah terkumpul sebagaimana adanya. Peneliti menggunakan jenis penelitian ini karena peneliti ingin menganalisa data dengan cara mendeskripsikan atau menggambarkan data secara sistematis dan akurat mengenai permasalahan dalam penelitian ini. Sehingga peneliti sendiri dapat lebih mudah mengetahui gambaran dari objek penelitian.

Penelitian kualitatif adalah suatu penelitian yang bermaksud untuk memahami fenomena tentang apa yang dialami oleh subjek penelitian misalnya perilaku, persepsi, motivasi, maupun tindakan dengan cara deskripsi dalam bentuk kata-kata (Moleong, 2017: 6). Langkah kerja untuk mendeskripsikan suatu objek, fenomena, atau setting sosial dalam suatu tulisan yang bersifat naratif. Artinya data, fakta yang dihimpun berbentuk kata atau gambar daripada angka-angka. Dalam menuangkan suatu tulisan, laporan penelitian kualitatif berisis kutipan-kutipan dari data/fakta yang diungkap dilapangan untuk memberikan ilustrasi yang utuh dan untuk memberikan dukungan terhadap apa yang disajikan (Satori dan Komariah, 2014:28).

Berdasarkan metode penelitian tersebut, peneliti berharap mendapatkan data penelitian yang bersifat deskriptif sehingga peneliti dapat menganalisis dan menelaah lebih dekat gambaran yang jelas mengenai penggunaan sumber belajar dengan pendekatan multiliterasi siswa kelas IX-C SMP Negeri 27 Tebo pada mata pelajaran PPKn. 
HASIL PENELITIAN DAN PEMBAHASAN Hasil Penelitian

Deskripsi Hasil Wawancara Penggunaan Sumber Belajar dengan Pendekatan Multiliterasi Siswa Kelas IX-C SMP Negeri 27 Tebo pada Mata Pelajaran PPKn

Sesuai dengan fokus penelitian, peneliti mewawancarai guru mata pelajaran PPKn, waka bidang kurikulum, dan siswa kelas IX-C (8 orang). Maka hasil wawancara dipaparkan berdasarkan fokus penelitian yaitu penggunaan sumber belajar dengan pendekatan multiliterasi siswa kelas IX-C pada mata pelajaran PPKn. Wawancara berlangsung pada saat informan tidak melakukan kegiatan belajar mengajar. Peneliti meminta informan untuk dapat menjawab pertanyaan dengan sebenar-benarnya yang berdasarkan fakta di lapangan.

Wawancara ini berdasarkan pada teori Yunus Abidin mengenai unsur unsur multiliterasi. Berdasarkan teori tersebut terdapat empat unsur multiliterasi di antaranya keteranpilan membaca, keterampilan menulis, keterampilan berbicara dan keterampilan penguasaan media dan media digital.

\section{Keterampilan Membaca}

Keterampilan membaca sebagai salah satu keterampilan multiliterasi menuntut pembelajaran hendaknya dilakukan dengan berlandaskan pada pengembangan kemampuan siswa untuk berpikir tingkat tinggi. Upaya ini dimaksudkan agar keterampilan membaca yang dikembangkan dapat bersesuaian dengan isi materi pelajaran lain yang memang dikemas secara lebih terpola dan sistematis. Mengenai keterampilan membaca siswa di kelas, peneliti mewawancarai informan yaitu guru mata pelajaran PPKn yang mengajar di kelas IX$\mathrm{C}$, hasil wawancara menyatakan:

"Dari yang saya amati, keterampilan membaca siswa itu ya hanya sekedar bisa membaca saja mbak. Namun untuk memahami isi bacaan, siswa masih kurang. Bahkan siswa sering salah dalam menjawab pertanyaan. Soalnya begini jawabannya lain. Namun ada juga siswa yang dapat memahami isi bacaan yang dibaca oleh siswa"

Berdasarkan hasil wawancara dengan siswa kelas IX-C yang bernama "S.N.H." menyatakan bahwa:

"Kalau membaca saya bisa mbak, tapi kalau memahami isi bacaan paling hanya sedikit yang bisa saya pahami mbak."

Selain "S.N.H.", terdapat pula tanggapan dari informan lain yang bernama "K.S." yang menayatakan bahwa:

"Kalau hanya membaca materi di buku ya belum paham mbak. Tapi kalau sudah dijelaskan sama guru saya bisa paham mbak"

Berdasarkan hasil wawancara di atas, diketahui bahwasannya keterampilan membaca pemahaman siswa masih kurang. Kebanyakan siswa hanya sekadar bisa membaca tanpa mengetahui makna yang terkandung dalam suatu bacaan yang dibacanya. Mengenai strategi membaca yang digunakan siswa dalam meningkatkan pemahaman terhadap suatu bacaan, berdasarkan wawancara bersama guru mata pelajaran PPKn, beliau mengatakan:

"Tidak selalu, karena dari strategi membaca yang digunakan siswa, ada yang dapat meningkatkan pemahaman siswa terhadap suatu bacaan dan ada juga yang tidak dapat membuat siswa memahami isi dari suatu bacaan."

Berdasarkan hasil wawancara dengan siswa kelas IX-C yang bernama "A.S." menyatakan bahwa:

"Tidak selalu mbak. Tapi biasanya saya baca berulang-ulang mbak, supaya saya bisa paham." 
Selain informan di atas, peneliti juga melakukan wawancara dengan siswa bernama "E.K." yang menyatakan bahwa:

"Jika materinya mudah dipahami ya saya cepat paham mbak. Tapi kalau materinya sulit dipahami ya harus dijelaskan dulu mbak supaya paham."

Adapun tanggapan dari "A.D." menyatakan bahwa:

"Kadang-kadang si mbak, tapi kalau lagi nggak konsen ya susah juga memahaminya mbak."

Berdasarkan hasil wawancara di atas, diketahui bahwasannya strategi membaca yang digunakan siswa tidak selalu memberikan pemahaman terhadap suatu bacaan. Hal itu tidak terlepas dari peran guru untuk menjelaskan materi yang tidak dipahami oleh siswa. Mengenai upaya yang dilakukan guru agar siswa mampu memahami berbagai informasi yang terkandung dalam tulisan yang dibacanya, berdasarkan wawancara bersama guru PPKn, beliau mengatakan:

"Biasanya yang Ibu lakukan ya dengan memberikan pertanyaan. Memberikan stimulus untuk memancing siswa mbak."

Berdasarkan hasil wawancara di atas, diketahui bahwasannya dalam membantu siswa memahami berbagai informasi yang terkandung di dalam tulisan yang dibacanya, guru melakukan upaya dengan memberikan stimulus berupa pertanyaan untuk memancing siswa menjawab pertanyaan terkait materi yang sedang dipelajari. Mengenai kegiatan siswa menggali makna atau istilah kata tertentu yang biasa digunakan dalam suatu pembelajaran. Berdasarkan wawancara bersama guru mata pelajaran PPKn, beliau mengatakan:

"Iya kadang-kadang mbak. Sebelum memulai pembelajaran ya membahas istilah kata kunci atau kata yang sulit terlebih dahulu yang biasanya digunkaan dalam pembelajaran."
Berdasarkan hasil wawancara di atas, diketahui bahwasannya guru sering menggali makna atau istilah kata yang sulit yang biasa digunakan dalam suatu pembelajaran, sebelum memulai pembelajaran agar memberikan kemudahan kepada siswa dalam memahami suatu materi.

\section{Keterampilan Menulis}

Keterampilan menulis sebagai bagian dari keterampilan multiliterasi menghendaki siswa mampu mengekspresikan ide dan gagasannya dalam bentuk tertulis. Isi tulisan yang dibuat siswa tentu saja akan sangat beragam sesaui dengan isi materi yang dipelajarinya. Mengenai kemampuan siswa menjelaskan ide dan gagasannya dalam bentuk tertulis, berdasarkan wawancara bersama, guru mata pelajaran PPKn, beliau mengatakan:

"Siswa belum bisa mbak membedakan dan memilah ide serta gagasan pokok yang tertuang di dalam buku. Jadi ya siswa hanya menyalin semua yang tertera di dalam buku. Seperti kemarin untuk menyebutkan kelemahan dan kelebihan orde lama dan orde baru. Di dalam buku kan tidak ada poin-poinnya. Di dalam buku itu kan hanya pernyataan saja. padahal kan bisa dibuat poin-poinnya. Tapi anak-anak tidak. Dia ya hanya menulis apa yang ada di dalam buku. Iya memang betul, tapi kan siswa tidak bisa untuk memilah-milah."

Berdasarkan wawancara peneliti bersama siswa kelas IX-C yang bernama "D.R.I." diperoleh hasil yang menyatakan bahwa:

"Bisa mbak, lagian kan jawabannya sudah ada di dalam buku mbak. Jadi ya tinggal ditulis aja mbak."

Selain “D.R.I." tanggapan yang hampir serupa diungkapkan oleh siswa yang bernama "K.S." yang menyatakan bahwa: 
"Sudah baik mbak, karena jika di beri tugas saya bisa menjawabnya mbak."

Selain "D.R.I." dan "K.S." tanggapan yang berbeda diungkapkan oleh siswa yang bernama "A.F.N." yang menyatakan bahwa:

"Kalau menulis pendapat saya ya masih kurang bisa mbak. Mau menyusun kalimatnya itu yang kadang saya nggak paham mbak."

Berdasarkan hasil wawancara di atas, diketahui bahwa siswa hanya mampu menulis apa saja yang tertuang di dalam buku, tanpa bisa membedakan mana yang penting untuk ditulis dan mana yang tidak penting. Mengenai upaya guru dalam mengatasi siswa yang mengalami kesulitan dalam menuangkan ide dan gagasannya dalam bentuk tulisan, berdasarkan wawancara bersama guru mata pelajaran PPKn, beliau mengatakan:

"Biasanya di dalam mengajar Ibu berjalan dan melihat apa yang ditulis siswa. Dan membimbing siswa yang mengalami kesulitan dalam menuangkan ide dan gagasannya."

Berdasarkan hasil wawancara di atas, diketahui bahwa untuk mengatasi kesulitan yang dialami siswa dalam menuangkan ide" dan gagasannya dalam bentuk tertulis, guru berperan membimbing siswa dan memperhatikan tulisan yang dihasilkan siswa. Mengenai kesesuaian tulisan yang dihasilkan siswa terhadap tujuan dan sasarannya, berdasarkan wawancara bersama guru mata pelajaran PPKn, beliau mengatakan:

"Tidak semua tulisan yang dihasilkan siswa itu telah sesuai dengan tujuan dan sasarannya mbak. sebagaian besar siswa belum memiliki keterampilan menulis. Siswa terbiasa hanya menyalin apa saja yang telah tertuang dalam google maupun buku tanpa dapat menulliskan ide dan gagasannya sesuai dengan pemahaman siswa sendiri."
Berdasarkan hasil wawancara di atas, diketahui bahwa tidak semua tulisan yang dihasilkan siswa sesuai dengan tujuan dan sasarannya. Karena sebagaian besar siswa terbiasa menyalin dari buku. Siswa belum dapat memilah poin penting yang terkandung di dalam buku.

\section{Keterampilan Berbicara}

Keterampilan berbicara harus dilakukan sebagai sarana berpikir kritis dan rasional dalam mengungkapkan berbagai ide dan gagasan yang dimilikinya. Mengenai kemampaun siswa dalam mengungkapkan ide dan gagasan yang dimilikinya dalam suatu kegiatan pembelajaran, berdasarkan wawancara bersama guru mata pelajaran PPKn, beliau mengatakan:

"Di dalam suatu proses pembelajaran siswa ya ada yang bisa mengungkapkan pendapatnya dan ada juga yang tidak bisa mengungkapkan pendapatnya."

"A.F.N." yang merupakan siswa kelas IX-C menyatakan bahwa:

"Kemampuan berbicara saya kurang baik mbak. Soalnya saya kurang percaya diri untuk menyampaikan pendapat saya mbak."

Hal yang hampir serupa diungkapkan oleh "A.D. yang menyatakan bahwa:

"kurang mbak, soalnya saya takut nanti salah jawab. Biasanya kalau salah tu kawan-kawan yang lain pada nyorakin gitu mbak."

Selain “A.F.N." dan “A.D.” hal yang berbeda diungkapkan oleh "E.K." yang menyatakan bahwa:

"Kadang bisa kadang juga enggak mbak. Kalau saya paham ya saya bisa menjawab pertanyaan yang diajukan guru mbak. Tapi ya harus sambil melihat buku mbak."

Berdasarkan hasil wawancara di atas, diketahui bahwa ada siswa yang mampu berbicara dan mengungkapkan ide 
dan gagasannya ada pula siswa yang belum berani mengungkapan pendapatanya. Mengenai pertimbangan giliran peran siswa untuk berbicara dalam suatu pembelajaran, berdasarkan wawancara bersama guru mata pelajaran PPKn, beliau mengatakan":

"Di dalam pembelajaran ya biasa mbak, siswa masih banyak yang berbicara serobotan tanpa mempertimbangkan giliran perannya."

Berdasarkan hasil wawancara di atas, diketahui bahwasannya dalam berbicara siswa belum bisa mempertimbangkan giliran perannya. Siswa lebih suka berbicara ramai-ramai daripada harus menyampaikan pendapat secara individu. Mengenai kemampuan berbicara siswa dalam suatu kegiatan diskusi maupun kegiatan berbicara lainnya dalam proses pembelajaran, berdasarkan wawancara bersama guru mata pelajaran PPKn, beliau mengatakan:

"Kemampuan berbicara siswanya ya masih kurang, di dalam diskusi saja hanya beberapa yang mau mengungkapkan pendapatnya. Sedangkan yang lainnya pasif."

Berdasarkan hasil wawancara dengan siswa yang bernama "A.S." menyatakan bahwa:

"Menurut saya ya cukup baik mbak. Jika sedang diskusi malah saya lebih senang menjawab pertanyaan dari kawan-kawan mbak."

Tanggapan yang berbeda diungkapkan oleh siswa yang bernama "R.S.R." yang menyatakan bahwa:

"Kalau sedang diskusi saya lebih banyak diam mbak. Biasanya kawan yang lain yang jawab pertanyaan."

Tanggapan lain diungkapkan oleh siswa yang bernama "D.R.I." yang menyatakan bahwa:
"Kalau sedang diskusi saya jarang berbicara mbak. Karena saya memang kurang paham sama pembelajaran PPKn."

Berdasarkan hasil wawancara di atas, diketahui bahwa tidak semua siswa memiliki kemampuan berbicara yang baik. Beberapa siswa aktif dalam berbicara sedangkan yang lainnya pasif. Mengenai etika berbicara yang baik yang dimiliki siswa dalam suatu pembelajaran, berdasarkan wawancara bersama guru mata pelajaran PPKn, beliau mengatakan:

"Terkadang siswanya suka main-main mbak, ketika sedang berbicara dengan guru saja matanya kemana-mana. Namun tidak semua siswa menunjukkan etika yang kurang baik. Ada yang menunjukkan baik ada pula yang kurang baik."

Berdasarkan wawancara di atas, diketahui bahwasannya tidak semua siswa memiliki etika yang baik dalam berbicara.

\section{Keterampilan Penguasaan Media dan Media Digital}

Penguasaan media dan mdia digital dapat memainkan peran pentingnya jika berbagai media dijadikan alat berpikir kritis dan digunakan dalam berbagai kegiatan inkuiri yang dilakukan siswa. Mengenai penggunaan media dalam suatu proses pembelajaran, berdasarkan hasil wawancara bersama Waka Bidang Kurikulum, beliau menyatakan bahwa:

"pada proses pembelajaran untuk media atau alat itukan disesuaikan dengan tujuan pembelajaran, karena ini sifatnya materi pembelajaran kewarganegaraan tentu alatalat peraga itu bisa dari karya siswa itu sendiri, bisa diciptakan oleh guru yang dikolaborasikan dengan hasil anak-anak, kemudian kita sesuaikan dengan tujuan pembelajaran atau topik pembelajaran yang ingin disampaikan pada hari itu."

Berdasarkan hasil wawancara di atas, diketahui bahwasannya penggunaan media haruslah disesuaikan dengan tujuan 
pembelajaran. Dan media pembelajaran bisa diciptakan berdasarkan hasil karya siswa maupun guru itu sendiri. Mengenai fungsi media di dalam suatu proses pembelajaraan, berdasarkan wawancara bersama guru mata pelajaran PPKn, beliau mengatakan:

"Mengenai media itu sendiri terkadang ibu tidak menyediakan mbak. Buku saja terkadang siswa malas membawanya pulang. Terkadang ditinggalkan di laci. Ada juga yang hilang."

Hal yang berbeda diungkapkan oleh Waka Bidang Kurikulum yang menyatakan bahwa:

"Ya artinya, karena untuk pencapaian tujuan pembelajaran alat bantu belajar berkaitan dengan media ya itu tentu menjadi target yang harus dimaksimalkan dalam penggunaannya. Selama ini pengamatan saya guru-guru bidang studi apalagi guru PPKn ya seperti diawal tadi saya sampaikan bahwa alat atau media pembelajaran sifatnya relatif bisa hasil karya siswa, hasil karya guru atau mediamedia yang memang ada di sekolah, yang digunakan untuk mencapai kegiatan pembelajaran kewarganegaraan. Maka mereka menggunakan secara maksimal berkaitan dengan tujuan pembelajaran yang akan disampaikan pada hari itu di kelas yang diampu."

Berdasarkan hasil wawancara di atas, diketahui bahwasannya penggunaan media di dalam proses pembelajarn harusnya digunakan secara maksimal untuk mencapai tujuan pembelajaran. Namun di dalam pembelajaran guru mata pembelajaran PPKn belum menggunakan media secara maksimal, di sisi lain siswa juga kurang memperdulikan buku paket yang dimilikinya sebagai sumber ataupun media belajarnya. Mengenai kesulitan yang dialami dalam hal pengguanaan media digital di dalam proses pembelajaran, berdasarkan wawancara bersama guru mata pelajaran PPKn, beliau mengatakan:
"Terkait media digital, jika di sekolah siswa tidak dapat menggunakan HP karena siswa SMP tidak diperkenankan membawa HP ke sekolah mbak. Namun, apabila diberikan tugas untuk dikerjakan di rumah ya siswa mampu menggunakan media digital seperti internet."

Berdasrkan hasil wawancara bersama Waka Bidang Kurikulum, beliau menyatakan bahwa:

"Digital ya, artinya kalau sifatnya tidak menggunakan jaringan internet, hanya menggunakan media digital saja seperti komputer dikaitkan dengan infokus kemudian kita tampilkan di layar sebagai bentuk pemaparan hasil belajar itu memang tidak mengalami kendala. Tetapi, jika menggunakan jaringan internet, kemudian harus memasuki lab. komputer kadang gangguan seperti jaringan agak lelet, padamnya listrik, hal itu tidak bisa dipungkiri karena itu di luar kendali sekolah."

Berdasarkan hasil wawancara di atas, diketahui bahwasannya penggunaan media digital apabila dihubungkan dengan jaringan internet sulit untuk diterapkan karena kendala jaringan intenet. Namun dalam hal penggunaan infokus untuk memaparkan materi pembelajaran sama sekali tidak mengalami masalah. Mengenai keefektivan penggunaan media digital dalam proses pembelajaran, berdasarkan wawancara bersama guru mata pelajaran PPKn, beliau mengatakan":

"Seharusnya penggunaan media digital itu dapat meningkatkan efektivitas dalam proses pembelajaran. Tapi kalau di sekolah itukan nggak boleh, nggak ada jaringan. Kemarin saja pas sekolah diliburkan karena covid-19 siswa hanya diberikan tugas secara online. Dan itupun tidak termasuk daring. Ibu saja pelatihan menggunakan zoom tidak bisa, karena terkendala jaringan."

Menurut Waka bidang kurikulum, beliau menyatakan bahwa: 
"Ya tentu saja. apalagi sekarang teknologi informasi dan komunikasi mengingat sangat berkembang pesat, jadi tidak hanya kajian teori melalui pemaparan di buku tetapi tentu melaui media-media digital kita bisa mengedukasikan pelajaran kepada anak, anak juga bisa menyerap informasiinformasi digital yang ada di layananlayanan media sosial, mereka akan lebih memahami jika mereka menemukan hal-hal yang sifatnya negatif, profokatif, maka melalui pendidikan kewarganegaraan mampu mengajarkan anak-anak. Karena media sosial biar bagaimanapun sangat berperan penting dalam suatu pembelajaran."

Berdasarkan hasil wawancara di atas, diketahui bahwasannya penggunaan media digital itu sendiri seharusnya dapat meningkatkan efektivitas dalam pembelajaran, karena dengan adanya perkemabangan teknologi informasi dan komunikasi tentu informasi-informasi tidak hanya dipaparkan melaui buku saja, tetapi penggunaan media digital tentu sangat berperan penting.

\section{Pembahasan}

\section{Deskripsi Hasil Observasi Penggunaan Sumber Belajar dengan Pendekatan Multiliterasi Siswa Kelas IX-C SMP Negeri 27 Tebo pada Mata Pelajaran PPKn}

Pada saat penelitian, ada beberapa kegiatan observasi yang peneliti lakukan di SMP Negeri 27 Tebo, khususnya di kelas IX$C$ yaitu antara lain:

\section{Hasil Observasi Tahap Perencanaan}

Hasil observasi yang dilakukan peneliti pada hari pertama yaitu pada saat peneliti datang ke SMP Negeri 27 Tebo dan menemui guru mata pelajaran PPKn untuk meminta data terkait Rencana Pelaksanaan pembelajaran (RPP) sebagai pedoman pembelajaran. Di mana di dalam RPP terdapat sumber-sumber belajar yang akan digunakan di dalam suatu proses pembelajaran. Berdasarkan RPP tersebut, peneliti mendapatkan bahwasannya guru mata pelajaran PPKn tersebut menggunakan sumber belajar yaitu buku paket mata pelajaran PPKn sebagai sumber utama serta pengalaman peserta didik dan guru sebagai sumber belajar lainnya. Adapun media pembelajaran yang akan digunakan di dalam suatu pembelajaran sangatlah beragam.

\section{Hasil Observasi Tahap Pelaksanaan}

Observasi pada tahap pelaksanaan yaitu peneliti melakukan observasi di kelas IX-C. Peneliti mengamati pelaksanaan pembelajaran di kelas berdasarkan RPP yang telah peneliti peroleh sebelumnya. Di dalam pembelajaran tersebut, guru melakukan kegiatan pendahuluan sesuai dengan pedoman pembelajaran yang telah direncanakan. Pada kegiatan pendahuluan guru melakukan apresiasi dengan tanya jawab mengenai materi pelajaran yang telah dipelajari di kelas VII dan VIII. Namun, pada sesi tanya jawab ini, hanya ada 1 siswa yang mengacungkan jarinya dan menjawab pertanyaan yang diajukan guru. Sedangkan siswa yang lainnya tampak begitu pasif. Pada kegiatan inti, guru membimbing siswa untuk membaca materi pembelajaran sebelum guru menyampaikan materi yang akan disampaikan.

Di dalam kegiatan pembelajaran, siswa hanya menggunakan sumber belajar yaitu LKS dan buku paket yang dimilikinya dari sekolah. Selanjutnya guru juga menyampaikan materi dengan metode yang digunakan yaitu ceramah. Karena waktu untuk pembelajaran PPKn hanya tersedia sembilan puluh menit (90 menit) dalam satu minggu. Guru menganggap waktu tersebut tidak cukup, sehingga materi pelajaran PPKn hanya dikembangkan dari acuan buku pedoman guru dan siswa tanpa menggunakan media pembelajaran secara optimal seperti yang tercantum di dalam RPP. Di dalam kegiatan 
pembelajaran, tidak ada kegiatan diskusi karena siswa yang mengikuti proses pembelajaran hanya 50\% dari keseluruhan siswa yang ada. Sehingga apabila dilaksankan kegiatan diskusi, maka tidak akan berjalan secara efektif.

\section{Hasil Observasi Tahap Evaluasi}

Observasi yang dilakukan peneliti selanjutnya yaitu adalah tahap evaluasi. Yang mana pada tahap ini peneliti mengikuti kegiatan akhir pembelajaran yang diizinkan oleh guru pengampu mata pelajaran PPKn di kelas IX-C. Pada tahap ini, guru memberikan tugas mandiri kepada siswa siswi kelas IX-C. Siswa pun mengerjakan soal-soal yang ada pada LKS masing-masing. Setelah selesai, tugas yang telah dikerjakan siswa dikumpulkan kepada guru. Kemudian, guru pun menyimpulan materi pembelajaran yang telah disampaikan. Selanjutnya guru memberikan tugas agar siswa membaca materi pertemuan berikutnya.

\section{KESIMPULAN}

Berdasarkan hasil penelitian dan pembahasan mengenai penggunaan sumber belajar dengan pendekatan multiliterasi siswa kelas IX-C SMP Negeri 27 Tebo pada mata pelajaran PPKn, maka dapat disimpulkan bahwa sumber belajar PPKn kelas IX-C di SMP Negeri 27 Tebo belum efektif. Sumber belajar yang digunakan masih berpedoman pada buku cetak dan LKS dari pemerintah. Hal tersebut dibuktikan dengan: Materi ajar RPP yang masih berpedoman pada bukubuku pemerintah seperti buku paket tanpa adanya buku penunjang lain dan wawancara dengan informan, yaitu guru mata pelajaran PPKn yang ada di SMP Negeri 27 Tebo.

Berdasarkan simpulan di atas, maka peneliti mengajukan saran yang dirumuskan sebagai berikut: Bagi Kepala dinas pendidikan, hendaknya melakukan program pelatihan terkait penggunaan sumber belajar dengan pendekatan multiliterasi kepada semua guru terutama guru mata pelajaran PPKn. Bahwa pendekatan pembelajaran saat sekarang sudah multiliterasi. Hal ini bertujuan agar dapat meningkatkan wawasan bagi peserta didik. Bagi pihak sekolah, melalui pimpinan yaitu kepala sekolah hendaknya sebaik mungkin dalam meyediakan sarana dan prasarana, terutama dalam penyediaan sumber belajar di sekolah. Bagi guru, sebaikanya menambah referensi sumbersumber belajar yang sesuai dengan materi ajar, sehingga dapat meningkatkan motivasi dan hasil belajar siswa. Bagi siswa, hendaknya siswa lebih aktif lagi dalam menggunakan berbagai ragam sumber belajar yang tersdia di sekolah.

\section{DAFTAR PUSTAKA}

Abidin, Y. 2018. Desain Sistem Pembelajaran dalam Konteks Kurikulum 2013. Bandung: Refika Aditama

,2018. Pembelajaran Multiliterasi (Sebuah Jawaban atas Tantangan Pendidikan Abad Ke-21 dalam Konteks Keindonesiaan). Bandung: Refika Aditama Ilmu Pengetahuan Sosial.

Afifulloh, Mohammad. 2019. Pemanfaatan Lingkungan Sekitar sebagai Sumber Belajar. Jurnal Ilmiah Pendidikan Dasar Islam. Vol. 1 No. 1

Asyari, Ahmad. 2018. Sikap Nasionalisme (dalam Pembelajaran PPKn). Lombok:CV Elhikam Press Lombok

Cahyadi, A. 2019. Pengembangan Media dan Sumber Belajar (Teori dan Prosedur. Kota Serang Baru: Penerbit Laksita Indonesia

Daryanto \& Karim, S. 2017. Pembelajaran Abad 21. Yogyakarta: Penerbit Gava Media 
Fatmawati, M.S., Pujiastuti, W., \& Septiwiharti, D. Pemanfaatan Perpustakaan sebagai Sumber

Belajar dalam Pembelajaran PKn di SMP Karuna Dipa Palu. Sulawesi Tengah

Karwati, Ekuis dkk. 2015. Manajemen Kelas (Clasroom Manajement). Bandung: Alfabeta

Moleong, J.M. 2017. Metodologi Penelitian Kualitatif. Bandung: PT Remaja Rosdakarya

Nurgiansah, T. H. (2018). Pengembangan Kesadaran Hukum Berlalu Lintas Siswa Melalui Model Pembelajaran Jurisprudensial Dalam Pendidikan Kewarganegaraan (Studi Kasus di SMK Bina Essa Kabupaten Bandung Barat Kelas X Administrasi Perkantoran). Tesis. Repository Universitas Pendidikan Indonesia, Oktober. http://ieeeauthorcenter.ieee.org/wp-content/uploads/IEEE-Reference-

Guide.pdf\%0Ahttp://wwwlib.murdoch.edu.au/find/citation/iee.html\%0Ahttps://doi.or g/10.1016/j.cie.2019.07.022\%0Ahttps://github.com/ethereum/wiki/wiki/WhitePaper\%0Ahttps://tore.tuhh.de/hand

Nurgiansah, T. H. (2019). Pemutakhiran Kurikulum Pendidikan Kewarganegaraan di Era Revolusi Industri 4.0. Prosiding Seminar Kewarganegaraan Universitas Negeri Medan, 1(1), 95-102.

Nurgiansah, T. H. (2020). Filsafat Pendidikan. In Banyumas: CV Pena Persada.

Nurgiansah, T. H. (2021). Pendidikan Pancasila. In Solok: CV Mitra Cendekia Media.

Rusvita, Y.A. Pemanfaatan Sumber Belajar dalam Proses Pembelajaran Pendidikan Kewarganegaraan (Studi pada Kelas VIII di SMP Negeri 2 Dlanggu) Kabupaten Mojokerto

Satori, D., \& Komariah, A. 2014. Metodologi Penelitian Kualitatif. Bandung:Penerbit Alfabeta

Sitepu. 2014. Pengembangan Sumber Belajar. Jakarta: PT Raja Grafindo Persada

Sugiyono. 2015. Memahami Penelitian Kualitatif. Bandung: Penerbit Alfabeta ,2016. Metode Penelitian Pendidikan (Pendekatan Kuantitatif, Kualitatif, dan R\&D). Bandung: Penerbit Alfabeta ,2018. Metode Penelitian Pendidikan (Pendekatan Kuantitatif, Kualitatif, dan R\&D). Bandung: Penerbit Alfabeta

Suprapto, H. 2016. Implementasi Lesson Study dalam Pembelajaran Pendidikan Kewarganegaraan Berbasis Video pada Kelas XII IPS SMAN 1 Ponorogo. Jurnal Dimensi Pendidikan dan Kewarganegaraan. Vol. 5

Supriadi. 2015. Pemanfaatan Sumber Belajar dalam Proses Pembelajaran. Lantanida Journal.Vol. 3 No. 2

Tabroni. 2015. Upaya Menyiapkan Pendidikan yang Berkualitas. Jurnal Kependidikan Islam IAIN Sultan Thaha Saifudin. Jambi

Tim Penyusun FKIP UNJA. 2018. Panduan Penulisan Skripsi Fakultas Keguruan dan Ilmu Pendidikan Universitas Jambi. Muaro Jambi: FKIP UNJA

Undang-Undang Republik Indonesia Nomor 14 Tahun 2005 tentang Guru dan Dosen

Winarti, Wijianto, \& Winarno. 2018. Analisis Sumber Belajar Mata Pelajaran Pancasila dan Kewarganegaraan di SMA Negeri 1 Kartasura.. Vol. 3 No. 1 